\title{
The Politics of True Crime: Vulnerability and Documentaries on Murder in Swedish Public Service Radio's P3 Documentary
}

\author{
Mats Hyö̈nen, Maria Karlsson and Madeleine Eriksson
}

This chapter investigates vulnerability in relation to P3 Documentary, a podcast format that has been aired by Sveriges Radio, Sweden's public service radio, since 2005 . It is the most popular radio programme in Sweden with 600,000 listeners weekly (Kantar Sifo 2019) and, bearing in mind that the country's whole population is only 10 million people, it is an influential authority.

A majority of the P3 documentaries recount themes related to vulnerability in various ways. However, the most common topic is crime,

M. Hyvönen $(\bowtie) \cdot$ M. Karlsson

Uppsala University, Uppsala, Sweden

e-mail: mats.hyvonen@antro.uu.se

M. Karlsson

e-mail: maria.karlsson@littvet.uu.se

M. Eriksson

Stockholm University, Stockholm, Sweden

e-mail: madeleine.eriksson@sofi.su.se

(C) The Author(s) 2020

291

A. M. Dancus et al. (eds.),

Vulnerability in Scandinavian Art and Culture,

https://doi.org/10.1007/978-3-030-37382-5_14 
staged in more than half of the programmes. The most frequent crime is murder. A selection of 19 documentaries on murder will be studied in this chapter, using a mixed-method approach with both quantitative and qualitative means. By analysing the choice of murder cases and how the documentaries are voiced and structured, the chapter will investigate how the emotional vulnerability of the listener is addressed. Emotions bring us together and tear us apart, Sara Ahmed writes, pointing towards the cultural and political work they perform (2004). Inspired by Ahmed, the overarching question in the chapter is how that work is carried out in the 19 programmes.

The concept of vulnerability will be described and the programmes will then be placed within the field of the study of crime and radio documentaries. Special attention is paid to how the narration relates to the aims of Swedish public service radio. This is followed by a quantitative analysis of the form and content of the programmes, which was undertaken by charting the length and ordering of voice sequences: the narrator, interviews, clips from other media, and of other kinds of voices and sounds. Finally, the question of the emotional invocations by way of form, voice sequences and content will be addressed. Three aspects will be analysed in this section: the representation of controversial cases, the use of fear and horror, and the function of experts.

\section{VUlnerability AND EMOTION}

There can be no doubt that media and vulnerability form a liaison in which different wounds - be they societal, individual, or environmentalare not only frequently acknowledged ethically, but are also exploited. This is certainly true of the crime documentary, a very successful genre in terms of the number of programmes available across both 'old' media, for example, TV, radio and cinema, and 'new', such as streaming services and podcasts. With its rewriting of the boundaries between the private and the public, and its focus on emotion and suspense (Horeck 2014), the modern crime documentary is a format that, to a considerable degree, both recognizes and feeds on different kinds of individual and societal vulnerabilities.

The $P 3$ documentaries on murder thematize the vulnerabilities of the victims, perpetrators, authorities and the justice system, and fulfil the media's mission to recognize vulnerability - the very condition required for bodies to be grievable at all (Butler 2004). This chapter, however, 
does not so much deal with recognition as with how the murders are represented, and what emotional work the programmes perform (Ahmed 2004).

It is important to keep in mind that the documentaries represent cases of subjects who are already injured addressing a listener that is injurable (Cole 2016). Although the documentaries thus re-present injuries, this chapter is primarily concerned with the ontological condition of the injurable listener ${ }^{1}$ as vulnerable. This approach corresponds with Sara Ahmed's understanding of vulnerability which she, in a discussion on fear of crime, defines as the subject's 'openness', its 'bodily relation to the world', that involves a sense of danger 'anticipated as a future pain or injury' (2004, p. 69).

To Ahmed, it is important that emotional attachments are understood as cultural practices, not psychological states that move from within and outwards to others $(2004$, p. 4$)$. Thus, the representation of murder cases invokes and assembles emotions in the listener, felt as fear, love, grief, anger, compassion and so on. It is crucial to understand that feelings and affects are already in the world when the subject arrives, and that they circulate in very particular ways (Ahmed 2004, p. 98). Emotions are, in other words, already attached to different things or objects when the subject is exposed to them, and the documentary listener is vulnerable to emotions linked to, for instance, victims, perpetrators, friends and family.

In addition, emotions are constantly moving about in culture, they 'move, stick and slide' as Ahmed puts it-but they also move the subject (2004, p. 14). The cultural and political work of emotions is that they push some subjects away while pulling others together (Ahmed 2004, p. 2). For instance, while some people are bound together by love's work of aligning, others are excluded by the same work-they can be feared and/or hated. This is a main mechanism in many attitudes, for instance, racism (Ahmed 2004, p. 52). How this emotional work of moving the listeners is performed by the documentaries will be exemplified in this chapter.

First, though: what are the specifics of the radio documentary, the crime documentary, and P3 Documentary? 


\section{Radio Documentary ANd Crime Documentary}

At the heart of documentary practice lies questions of truth and reliability. Documentary makers claim to show and speak the truth, and their audiences expect to receive 'truthful representations of facts and trustworthy arguments' (Werner 2016, p. 1048). However, the claim to truth finds different expressions in different kinds of documentary and in different kinds of media, and key in much research on the documentary is how the relationship between reality and representation is to be understood.

In a documentary, the representation of reality is neither completely false nor objectively true (Bruzzi 2006). Rather, truth is the result of a negotiation between the documentary and its subject. Thus, the relationship between reality and representation can be seen as a productive, dialectical one (Bruzzi 2006, p. 6). In this negotiation, the narrator is a constituent part, no matter what opinion one has on the claim of truth (Bruzzi 2006, p. 72). This is not least true for the film documentary, to which researchers of radio often turn (cf. Crook 1999; Hedemann 2006; Björkman 2009; Lindgren 2011; Åberg 2012; McHugh 2012, 2014).

Nichols $(1991,2001)$ has discussed the narrator's significance to different modes of documentary filmmaking. In its most traditional form, 'the expository mode', the voice is authoritative. The narrator, referred to as 'the voice of God'-a position of power-leads the viewer through the images, and the voice-over explains their meaning and puts them in context. In more recent forms, however, such as 'the observational', the voice is absent. Here, pure observation through sound and image derives its authority from the supposedly objective mimesis. Again, Nichols (1991, 2001) refers to an omnipotent address, and a powerful logos oriented argumentation.

Bruzzi argues that the narrator's voice is stereotypically discredited by Nichols, since it is based on a belief that objectivity is, in fact, achievable. She asks what would happen if the voice was not seen as an instance of omniscience or objectivity but, rather, as one of an inquiring helplessness? ' $[\mathrm{E}] \mathrm{ven}$ when it is most conventionally used $[\ldots]$, the limitations of the voice-over do not preclude the possibility of an alternative interpretation being left open and accessible to the audience', Bruzzi explains (2006, p. 72). It is therefore reductive to not distinguish between different uses of the voice within the single documentary (Bruzzi 2006, p. 58). The style of narration may resemble that of the 'voice of God'-for example, 
by being factual-but does not necessarily have the pretentions of being authoritative and all-knowing.

All documentaries, however, make claims to truth and thus speak with authority. The question is how this is performed. Since the radio documentary on crime is the object here-what is the role of the narrator and other voices in this format? According to Werner (2016, p. 1050), the expository mode dominates the field of criminal law, and therefore 'most documentaries $[\ldots]$ have a rather moralizing and educational tone-they come with a message'. Since the verbal message is central, and is important for the way in which, for example, victims are portrayed, the argumentative set-up of expository documentaries runs the risk of reducing the complexities of individuals and their lives to mere illustrations of the central message (Werner 2016, p. 1051). This is the case of so-called 'True Crime', a term used to include 'any true accounts or case studies of real crime and its aftermath' that often refers to documentaries 'using an investigative mode either to "solve" or to recall the details of notorious murders or other atrocities' (Biressi 2004, p. 402). True crime roots back to pamphlets by British authors between 1550 and 1700 reporting on capital crimes (MacMillan 2016) and, later, to Truman Capote's and Norman Mailer's influential True Crime paragons. It has become a hugely popular topic. What counts as True Crime has changed over the years, though. Today, they are exaggerated in style and strive to impact real cases (Bruzzi 2016, p. 267). The ambition to have influence on legal cases leaves little room for doubt, and fits well into the kind of authority that the expository mode evokes. In these thesis-driven documentaries, the voice-over must be certain-it is a vital part of the convention.

But what about crime documentaries within a public service context where claims of being impartial and truthful are essential? And when there are no images-how are objectivity, authority and power represented? While, in film, it is possible to talk about the course of events and simultaneously show related visual material, radio is limited to forefront one element at a time, accompanied only by sounds. How then, if at all, is the balance between impartiality, truthful authority and intriguing storytelling achieved in relation to the vulnerable listener? 


\section{$P_{3}$ DOCUMENTARY}

Documentaries are thriving on TV and streaming services such as Netflix and $H B O$. A hunger for reality has made its presence felt since the early 1990s, and there seems to be a never-ending demand for authentic stories. Theories put forth to explain this success include the rise of reality TV and the renegotiation of boundaries between the private and the public in the age of social media (Massumi 2002; Skeggs \& Wood 2012; Horeck 2014). The ongoing 'documentary boom' (Austin 2007) is partly also explained by the new marketing opportunities and distribution forms opened up by digitization.

One prominent example of this is the podcast, its advantages over traditional radio being that, for example, you can listen when and where you want to a wide range of niche programmes. Podcasts of various kinds are rapidly growing in popularity. In Sweden, between 2015-2018, the share of people over the age of 12 who listen to podcasts at least once a month increased from 18 to $30 \%$. About $70 \%$ of Swedes in the age group between 16 and 35 years listen monthly, and more than $35 \%$ of them tune in on a weekly basis. It is now more common for people aged between 16 and 25 years to listen to podcasts than to FM radio (Davidsson \& Melin Mandre 2018). In 2018, 12 Swedish podcasts attracted a weekly audience of over 100,000 people. The biggest by far was P3 Documentary, which is one of Sveriges Radio's most successful programmes ever with its 600,000 listeners.

Most of the episodes are downloaded via iTunes, which indicates a primarily young audience (Sveriges Radio 2016). Sveriges Radio describes the programme as a 'gateway to [Sveriges Radio's] wide range of documentaries' on all its channels (Sveriges Radio 2016, p. 79). ${ }^{2}$ Furthermore, P3 Documentary serves as a part of Sveriges Radio's self-legitimation as a public service institution because it successfully combines popularity with serious content. Sveriges Radio's channel P3 targets a younger audience. Music and entertainment are major elements, but it also aims to involve the listeners in current social issues. In this context, P3 Documentary is important, since it is 'a perfect example of how complicated [...] events and developments are explained, deepened, and packaged in such a way that it becomes attractive to a broad audience' (Sveriges Radio 2017, p. 18). 'The purpose of the documentaries', according to Sveriges Radio itself, 'is to portray important events in modern Swedish history in order to better understand the present times' (Sveriges Radio 2015, p. 52). 
P3 Documentary is a good example of the abundant documentaries on crime, which are gaining in cultural prominence and resonance (Bruzzi 2016). Even though P3 Documentary is not entirely committed to crime, a dominant portion of its programmes deal with it: of the 260 programmes published as podcasts from the start in 2005 until 2017, 137 $(53 \%)$ are on crime. Murder occurs in 43 programmes, which makes it the dominant theme among crime documentaries.

The $P 3$ crime documentaries on murder share traits with film and TV documentaries, but they also differ. While the former evoke doubt by presenting previously unknown facts, and challenge verdicts, the justice system and the actions of authorities, P3's aim seems to be to remain neutral on issues that have been widely debated. This does not mean that they refrain entirely from remediating critique of, for instance, authorities' actions; and they navigate through the cases by choosing certain angles and facts that give an indication of the programme-makers position. None of the programmes can be said to advocate an explicit, strong opinion, though. First and foremost, they retell the events of spectacular murders. In fact, the only 'news' presented is initial interviews with family members and friends.

All 19 documentaries in this study deal with well-known cases, and many of them have had a political, social and legal impact on Swedish society. Examples of this are the murder of Swedish foreign minister Anna Lindh in 2003, the honour killing of Fadime Sahindal in 2002, the murder of a 10-year old girl, Engla, by a stranger, and Therese Johansson Rojo, murdered by a boy from her school. All these cases received extensive attention in the national media (in three cases, the funerals were broadcast on national TV) and they can, in terms of public indignation, be described as national traumas subject to collective mourning.

The ambition of the documentaries is to retell, and in part to re-enact, these widely known cases. With very few exceptions, the programmes stick to the same formula: to tell the stories mainly chronologically, based primarily on information from the police investigations. The programmes in themselves are not explicitly controversial, but some of the cases chosen are, and one question is how this is dealt with, considering the public service aim of impartiality. In this, not only is the role of the narrator crucial, but also the degree to which attempts are made to move the audience, to create suspense and to sensationalize the circumstances.

To discuss the function of different kinds of voices and, not least, the ways in which they potentially move the listener, an analysis of individual 
clips was conducted to map the order of events guided by the different voices, and to measure their length compared to the run-time of the programme. ${ }^{3}$ The dominant voice turned out to be that of the narrator $(27.8 \%$ of the average programme run-time). How then, should the typical narrator of the 19 programmes be described?

The narrator's position is, to begin with, seemingly objective, linking together content and guiding the listener through the case material in a basically chronological pattern. Any criticism is conveyed implicitly through other voices, such as experts with whom interviews are conducted, usually without the questions being included. Through the voices, but also, of course, by the ordering of and choice of content, it is possible sometimes to discern standpoints. Straightforward critique is only expressed when the programmes deal with media ethics. This neutral stance may reflect Sveriges Radio's ambition to be correct, independent and impartial (Sveriges Radio 2014).

But are the P3 documentaries on murder 'impartial' and, therefore, 'neutral'? The following section addresses this question by analysing two documentaries where the murders have been committed by immigrants at a time when migration is Sweden's most controversial issue. It suggests that, in highly charged cases, the effort of maintaining a neutral stance does not achieve the intended impartiality due to the format's dedication to suspense and sensationalism. Both cases are retellings of so-called 'honour killings', committed at the beginning of the millennium. The first programme, in 2005, is juxtaposed with one from 2016, by which time the P3 Documentary format has become more streamlined. What emotional work is done when a highly charged murder case is retold in a format aimed at being attractive to more than half a million young listeners?

\section{$P_{3}$ Documentary and the Controversial Case}

'The Murder of Fadime Sahindal' is from 2005 and is the first programme aired in P3 Documentary. It deals with a case that can be described as a brusque wake-up call for the Swedish public regarding honour killings. Fadime Sahindal was active for young immigrant women's rights, and had influential friends in politics. She had a Swedish boyfriend who was not accepted by her family and had to go into hiding. In 2002, she was murdered by her father outside her sister's apartment. The case created intense and long-lasting discussions. Fadime was collectively mourned in 
Sweden; the public funeral was broadcast on TV and attended by both politicians and members of the royal family.

The documentary not only tells the story of the murder, but also clearly aims to inform the public on a crime about which Swedish society had little knowledge. The case is calmly and cautiously retold from a wide perspective (the narrator's voice takes up only $19 \%$ of the runtime, and 10 different people's voices are heard). The contextualization accounts for the pressure put on Fadime's family from relatives in Sweden and elsewhere. Fadime's political work and private struggles, memories of her, and the way she is mourned are also recognized. Care is given to the manner in which the programme ends: church bells from the funeral open the programme as well as close it, and those who attended the funeral acknowledge the grief of the relatives that were present.

Since the presence of the narrator's voice is relatively limited, the mode of this documentary can, in Nichol's (1991) terms, be characterized as observational rather than expository. However, the attention to context and the calm and cautious tempo does not imply authority and omniscience. If anything, the narrator is inquiring (Bruzzi)—which is unusual in crime documentaries, where the 'voice of God' dominates (Werner 2016 , p. 1050). The focus on complexity, recognition and closure, rather than on the promotion of suspense and sensation, leaves a range of possible positions open to the listener-one being the ability to understand the tragedy from the point of view of the Sahindal family. The documentary does not stir up hate and fear but, rather, sadness and compassion, pointing in several directions. It fits within the $P 3$ aim to be impartial, correct and independent.

'The Honour Killing of Abbas Rezai'-aired more than 10 years after the Fadime Sahindal documentary, and a decade after he was murderedis different. This may be due to the fact that, by this time, the documentary format of $P 3$ had found its form. It is more spectacular, plot oriented, driven by suspense and focused on sensation. Many passages are preceded by music or other sounds. Any opportunity to withhold information is taken. The narrator appears to be all-knowing, takes up more $(38 \%)$ of the run-time ${ }^{4}$ and drives the chain of events forward chronologically, rarely pausing to broaden the context. In other words, the melodramatic aesthetics of 2016 create an air of crime fiction.

In addition, there has also been a change in Sweden's political landscape. In 2016, immigration is debated on a daily basis in media and 
society. In 2005 , the nationalist movement was certainly growing in Sweden, but the biggest party-the Sweden Democrats: hostile to immigration, with its roots in a neo-Nazi party-was still not in parliament. From 2014 onwards, though, the Sweden Democrats have occupied about 15\% of parliamentary seats, and the party is an influential, increasingly normalized actor in Swedish politics. The Sweden Democrats is primarily addressing the fear of immigration (research has partly related that fear to the country's rapidly growing economic gaps; see, for example, Therborn 2018). Sweden counted its highest number of migrants ever in 2015163,000 (Migrationsinfo.se 2019) —and its capacity to deal with them, as well as the terms for asylum, has been and still is the topic of intense discussion. In other words, P3 could take for granted that a documentary on the honour killing of Abbas Rezai would become a part of these discussions.

Nineteen-year-old Abbas came alone to Sweden from Afghanistan a year before he met and fell in love with Mariam, a young Afghani woman. According to comments made by a friend in the documentary, Mariam was controlled by her brother, had to wear a veil and was not allowed to meet male friends or to use the Internet unsupervised. According to the programme, she was supposed to marry a cousin approved by her high-status family. Abbas' family was of low rank, and he could not be considered acceptable. Mariam ran away to Abbas. Eventually, she called her mother though, who claimed that the family had changed its mind and persuaded the couple to come to visit them. So, Mariam and Abbas headed to Högsby to celebrate their engagement: but, the listener is warned, Mariam's family had other plans. Mariam was drugged so as to make her sleep, and Abbas was killed. No details are withheld. Information on the horrific torture of Abbas is repeated several times, as well as have been sign-posted at the beginning of the programme. Recordings from the trials repeat the information again. An investigator states that this is the worst case of which he has ever heard, and this is also repeated. The conclusion of the affair-where the brother, who took the blame, and Mariam finally bear witness against their parents-is a climax that has been enigmatically hinted at earlier. In the closing section, there are a few contextualizations from Högsby. One is a speculation on the case's effects on a local election, where the Sweden Democrats party's share of the votes rose. It is supported by an interview with a Sweden Democrats politician. Another is the information that Högsby stopped all immigration-with the support of the migration authority-because of 
the murder. At the very end of the programme, the head of immigration coordination in Högsby expresses her relief that the building where the 'shameful' murder took place has been torn down.

What does this documentary $d o$ in terms of emotion? It is evident that the programme's proximity to the intense debate on migration in Sweden-where fear of violence and immigrants is a major theme-evokes emotion.

The documentary, then, is clearly structured around an opposition of good and evil. It is invested in securing the 'Swedishness' of Mariam and Abbas, who are positioned as typical teenagers set in the Swedish culture: school, the library, playing soccer; and friends are interviewed. Mariam's family though, which is claimed to see itself as high-status Afghani-as 'descendants of Mohammed'-is not described by anyone, and we are not given any information about their daily life. What the listeners find out about the parents, besides the horrific nature of their behaviour, is that they made their daughter wear a veil, kept her under strict surveillance, and aimed to marry off her to a cousin in exchange for money. In a short, re-mediated interview, the parents blame Abbas for the events. An interpreter assists at the interview, indicating that the parents do not speak Swedish. ${ }^{5}$ Thus, through a process of 'othering' (Ahmed 2004, p. 16), Mariam's parents are positioned as the un-Swedish others who are unintelligible and dreadful.

In addition to the tension between good and evil, another melodramatic trait is used in the documentary - the overdetermination of detail: Mariam's veil. It is mentioned a number of times in the programme. First, in the beginning, when the listener learns that Mariam had to wear a veil. Then on the run, in Abbas' home, where she does not wear it. Back with the parents, she wears it again, but at the trial, when she bears witness against her parents, the veil is off ('Without veil, with two bodyguards'). The veil is a good example of what Ahmed calls a 'sticky' object (2004, p. 11). A sticky object, or a sticky word, is, according to her, imbued with affect. It invokes emotions that circulate in culture and between bodies, and pulls people together into communities or nations (Ahmed 2004, p. 89). The repeated reference to the veil in the programme therefore moves the listener. It is used as a sign glued to the hateful other culture to which the parents belong. The unveiling, then, proves to the listener that Mariam does not belong to the other, that she is not part of their hate that threats Swedish values, the national subjects, and, ultimately, the nation as a whole. 
The 'emotional reading of others as hateful' ties the white nation and its imagined subjects together, Ahmed writes (2004, p. 43). The repetition of the details of the detestable torture of Abbas that are heard and repeated in the programme may invoke such readings. Following Ahmed's thought on the emotional mechanisms of racism, this is due to a fantasy where the hateful threatens the ordinary-it is in a crisis-and the ordinary person becomes the real victim of the hate. 'The ordinary becomes that which already was under threat by the imagined others' (Ahmed 2004 , p. 43). The injured-Abbas-becomes the normative subject, and the hateful-the parents - turn into the hated others. This hate is, says Ahmed, spread out in different directions across figures that threaten different kinds of losses; for example, lost jobs, lost land, lost non-violated and pure bodies. The metonymic slide does the work of making crime synonymous with migration, and what makes the migrants resemble each other is their 'unlikeness' from 'us' (Ahmed 2004, p. 43).

This unlikeness is expressed in the interviews with Högsby representatives. The speculations on how the Sweden Democrats votes rose after the murder, and the municipality putting a stop to immigration because of it-sanctioned by the migration authority-point to the metonymy being at play, as does the closure the programme offers. The last words go to the former head of local migration coordination, who comments on the torn down apartment house where the murder took place. It was a symbol of the shameful, she says, and therefore she is happy that the house no longer exists.

Although the narrator's voice takes up $38 \%$ of the programme, it never takes the time to explain or nuance the chronologically presented events. There is no attempt to educate the listener, either on legal matters or on the decade-long ongoing discussion of honour killings in Sweden. The documentary sticks to a dramatized formula where distance, a critical journalistic stance and contextualization are absent. In fact, the reference to melodrama in the analysis above is important. Once a theatrical form, the genre's mix of strong sentiments, the spectacular, iteration and moral polarization was a way to appeal to large audiences. By means of, say, the silent film and melodramatic traits in fiction, its aesthetics was inherited by block buster Hollywood movies (Brooks 1995). Melodramatic elements are key in crime fiction and have been associated with reality TV (Skeggs $\&$ Wood 2012). In the controversial cases of P3 Documentary, the use of melodramatic traits complicates the public service aim of impartiality. It moves the listener and it does political work. 
The above analysis implicates that the choice of murder cases, in relation to how they are moulded by the format, is important to how the listener is moved. So, how does P3 Documentary select its murders?

\section{Women and Children, Fear and Horror. $P_{3}$ Documentary's Selection of Murders}

According to Arthur (2005), there is a greater need in society for an emotional connection with real-life stories in the context of post $9 / 11$ terrorism, but this trend was already visible in the rise of the reality TV that predated it. Bruzzi shares this observation when describing the film documentary as often 'emotion-driven, sensual, and [...] primal in its appeal' (2006, p. 248), in opposition to Nichols' view of the (film) documentary as intellectual, cerebral, and sober (Nichols 1991, 2001). Thus, the P3 documentaries on murder correspond to the trend in the present documentary boom when it comes to the emotional, even though they do not explicitly 'whip up social outrage by campaigning against wrongful convictions' or expose 'gross injustices' (Horeck 2014, p. 152).

As the P3 Documentary format becomes more established, the programmes are increasingly focused on emotions that attach to ideological and political tendencies in society. The selection of murder cases certainly bears witness to this trend. It is not motivated in relation to a more general idea anywhere, more than the aim to 'portray important events in modern Swedish history in order to better understand the present'. In the documentaries on murder, these 'important events' do not align with actual crime statistics. This is probably due to two factors. First, the programme-makers need cases regarding which there is a great deal of archive material. Second, they focus on the most spectacular cases.

According to the Swedish National Council for Crime Prevention, murder victims are often young men from socially vulnerable areas (BRA 2014). Of the 113 people killed as a result of lethal violence in 2017, only 27 (24\%) were women (BRA 2018). Typically, when women are the victims of murder, the perpetrator is their male partner and the crime is committed at home. In addition, lethal violence against children is extremely rare-about four to five cases are reported every year. Yet, of the 19 episodes of P3 Documentary that deal with murder, 14 are about cases in which women or children were the victims ( 9 women and 4 children). Furthermore, in 7 of these cases ( 3 children and 4 women) -9 , if 
one counts the cases where the victims were men-the perpetrator was unknown to the victims.

Many of the selected murder cases are reminiscent of horror movies and take place in nightmarish circumstances. A majority of the programmes describe how the victims were subjected to torture, sexual assault, and/or unprovoked assaults by strangers. Often, the perpetrators are people with whom the victims have an intimate relationship: parents or loved ones. The injuries on the bodies of the victims, and, not least, the places in which they were encountered, invoke horror film clichés: they are found deep in the woods, submerged in water, hidden under rocks and, in two cases, the perpetrators had tried to set fire to the bodies to destroy evidence. The listeners are taken along on reconstructions where the perpetrators point out the scene of the murder and describe in detail what happened. With the exception of four documentaries (in which the killings were related to gang violence, football hooliganism, drug dealing, and the antagonism between skinheads and immigrant youth) all the programmes draw on a horror film lexicon (Biressi 2004) with perpetrators who are unknown and, often, mentally ill, or, which is equally frightening, parents who murder their children or partners who kill their loved ones.

Fear is obviously crucial to the programmes. Considering that more than half of the victims are female, and that the documentaries have farreaching claims to the truth, they retell the narrative of women being particularly vulnerable, especially outside their homes. However, women's fear is, as Sara Ahmed has argued, not an effect of their 'inevitable vulnerability'; rather, it is a 'response to a threat of violence' (Ahmed 2004, p. 69). According to her, stories of women's vulnerability circulate as authorized narratives of what should be considered as dangerous and the places of which to be afraid. The $P 3$ documentaries on murder contribute to these narratives. Although it is a widely known fact that most murders of women $(80 \%)$ in Sweden are committed by their partners, and almost exclusively at home (Forselius \& Granath 2017), the documentaries persuasively suggest that women should be on their guard when moving outside alone. The safe place for women is at home, thus moving unaccompanied in public becomes illegitimate, inappropriate and irresponsible. The many narratives of danger and safety in the documentaries suggest a restriction of women's access to public space (Stanko 1990). The 'mobility of some bodies involves [...] the restriction of the mobility of others', and 'what is fearsome as well as who should be afraid is bound up 
with a politics of mobility' (Ahmed 2004, p. 70). So when, for instance, at the end of 'The Murder of Elin Krantz' (2017) —another highly controversial case, where a migrant raped and killed a young Swedish woman in a suburb, at night-her friend says that she will never go on public transport at night again, it is a lesson on mobility.

The cases chosen by P3 Documentary and the staging of the events are thus not culturally and politically innocent. Additionally, the threat conjured up in the programmes is not only mainly directed at teenage girls and adult women, but also at female children. Two of the documentaries describe cases in which 10-year-old girls were kidnapped, raped and murdered when they were outside playing; one programme deals with the murder of a four-year-old girl playing outside her preschool. In all these cases, the perpetrator was unknown to either the children or their families.

\section{FAMILY, MURder, INTIMACY}

The most emotionally charged voices in the documentaries belong to the families and to the friends of the victims. This group represents the people actually injured, and they amount to more than one-fifth $(22 \%)$ of the total run-time of the 19 documentaries. A few examples show the often very intimate level of the representation of these voices. Actors read text messages, full of love and hate, sent between two 15-year-old perpetrators who, in a love triangle, conspired and murdered their classmate ('The Murder of Therese Johansson Rojo'). There are interviews with mothers, such as Engla Höglund's ('The Murder of Engla Höglund'), or siblings who's voices break - the sister of Elin Krantz, for instance.

To involve close ones is crucial to the documentaries on murder. The interviews with family members are not only presented as new information in the promotion texts, they are P3's main contribution, since the rest of the case already has been reported by different kinds of media and, in some cases, even retold in books and TV documentaries.

People that were close to the victim are also used as a reminder that anyone of us could have been the victim-our children, siblings, partners, friends. Where did the victims grow up, what did they like to do, who were they, ${ }^{6}$ were they happy? This information is presented through interviews with friends and/or family usually at the beginning of the programmes. The listener knows that this loss could have been my loss. This 
identification produces a 'likeness' between the listener, the family members and the victims. Thus, it aligns the listeners with the victim. Simultaneously, it pushes them away from the perpetrator, since what aligns with some others, aligns against different others (Butler 1997; Ahmed 2004, p. 52).

The aligning of the listener with others can be framed within what Berlant (2008) has termed 'the intimate public', which she defines as a 'porous affective scene of identification among strangers that promise a certain experience of belonging, and provides a complex of consolation, confirmation, discipline and discussion about how to live'. The experiences of belonging are created 'in proximity to the technologies that make "it" a site of affective investment and emotional identification' ( $p$. viii). A part of that site of intimacy is the device that brings the message across. Grusin (2010) has noted that the Abu Ghraib photos did something beyond present their horrific content. People recognized the use of media, the photos were 'not fundamentally different as media practices than what we do with our digital cameras [...] when we capture scenes of a wedding or a birthday'. This made the experience a 'bodily feeling both of the affectivity of these digital images and of the affinity between our own practice of distributing affect across and through other media' (Grusin 2010, p. 89).

Drawing on Grusin's example, Horeck (2014) has discussed intimacy in the light of the use of common media practices - in her case, home videos-in crime film documentary. One can argue that a similar bodily identification with media practices exists in, for instance, the context of reality TV, which often takes place in a home and usually is watched in a home (Skeggs \& Wood 2012). But, in the crime documentary podcast, or in the Abu Ghraib case, the device itself 'draws attention to the potential proximity of such documentary images to crime and death' (Horeck 2014 , p. 160), and, of course, corresponds with the audience's own ways of distributing photos and different kinds of affect via their technical devices.

Listening to the documentaries on murder via podcast is, in other words, a specific digital experience similar to that addressed by Grusin and Horeck. Pictures and videos cannot be shown, but the majority of the P3 documentaries contain reports on the mobile phone usage of victims, perpetrators and witnesses. Text messages are read out aloud, referred to as evidence, or included to set the case in a sentimental context of love, family and friends. While the audience is listening to the podcast on 
their phones-on the move, perhaps simultaneously answering a text message - the bodily practice of using them is recognized in the programme, and is connected to a context of murder. As Grusin (2010) points out, the feeling of proximity is bodily both through the content of the messages and the way the listeners themselves use their phones.

When it comes to sites of intimacy, it is also worth highlighting the temporal clash between the private and the public. A text message sent before a crime - or even during a crime - can be retrieved and then broadcast publicly. This marks out a new relational area between the public and the private that Massumi calls the 'quasi-public' sphere (2002). It is a site where the media user is aware that others are present, even though the communication is directed at family, colleagues or friends. The increased representation of media practices in art and other media creates affinity, but also attaches to a sense of paranoia: 'What if my messages one day become public?'

Another function of the affinity created between the listeners through interviews with families is that reaffirming family is, and always has been, a part of the conservative strain of mediatized crime. Narratives of crime 'appear to reinforce conventional ideals about love, family and society', since it frames the victim within them, and triggers and strengthens the cliché (Jermyn 2007). This has been the case throughout the history of melodrama, where crime and the justice system have played a significant role. Crime was connected to the unsubtle hammering in of bourgeois family values through a matrix of oppositions, guided by good or evil. The villains were always a threat to the family, especially innocent women and children (Brooks 1995). The P3 podcast documentaries on murder make visible how persuasive these values still are and, not least, the ontological vulnerability of the listeners in relation to them.

\section{The Function of Experts}

Another instance that can have a political impact on the format and the listener is the expert. Different kinds of experts appear in the programmes: representatives of the justice system (prosecutors, lawyers and the police), other experts (criminologists, medical expertise, journalists), and employees of societal institutions (social services, politicians, health care workers, schools). They make up about $27 \%$ of the average programme's run-time (the retellings from the police investigations and verdicts by the narrator have not been included). These official voices are, in relation to the truth, 
a significant part of what makes a documentary into a documentary, and not fiction.

According to Werner (2016, p. 1043), documentaries have become 'important tools for education and the spread of imageries of [...] criminal justice'. The $P 3$ documentaries on murder do spread such 'imageries', but they do not educate-in fact, they rarely use the experts to explain the law at all. Judges or criminal law researchers are not used to explain the differences between, for example, different kinds of intent, or how murder is distinguished from manslaughter, and so on. Lawyers and prosecutors are also rarely addressed as professionals. In the documentary on Fadime Sahindal, for example, the lawyer is mostly addressed as a friend. Instead, the focus is on criminology_profiles of serial killers and crime statistics - psychology, or the dealing with criminals and victims within social services.

Since we are dealing with the staged, dramatized reconstructionextracts of events re-presented and neatly tied together for the sake of suspense-of already highly mediated murder cases, many of the sources of facts are already charged with different emotions in relation to the audience. For instance, most of the professionals interviewed have previously appeared in different kinds of media-not least other documentaries.

In addition, facts are often delivered by celebrities. It may be a star lawyer-Peter Althin or Leif Silbersky, or a renowned professor of psychiatry, such as Sten Levander. Or, as in 4 of the 19 programmes, the retired professor of criminology and crime fiction writer Leif G. W. Persson. For years, he has been an expert in popular crime TV shows and a celebrity continuously cropping up in the media. Thus, his function in P3 Documentary is not only to educate the listener in matters of criminology - an air of suspense attaches to him, of cases that have been hard to solve - and of crime noir.

Persson is part of the Nordic crime fiction success. Like many others, he is influenced by the Swedish author alias Sjöwall/Wahlöö (Per Sjöwall and Maj Wahlöö) who, in the 1960s, renewed the genre (Wendelius 1999; Berglund 2017). Their novels focus on worn-out policemen, carrying out their life-consuming work in a decaying welfare state. This twist of the genre became the Nordic noir, nowadays endlessly televized and filmed (Berglund 2017).

The public is familiar with crime fiction conventions, and the use of them is routine in the crime documentary (Arthur 2005, p. 20; Horeck 
2014 , p. 152). The interrelatedness of crime fiction and the documentaries on murder is obvious, not least in the promotional texts. As in the marketing of crime fiction, certain information is withheld, and the condensed themes are often presented as though the programme is a thriller or a horror story. P3 Documentary 'tells a story about a culture of silence, jealousy, revenge, murder and drugs' ('Our Restaurant and Bar'); or 'tells the story about when the unimaginable happens four days before high-school graduation day: On murder, love, and obsession in a teenage world' ('The Murder of Therese Johansson Rojo'); or 'tells the story about unparalleled violence, assault, and torture' ('The Case of Bobby').

The Swedish welfare state-once meant to overcome vulnerability by means of social engineering - is today moving closer to what literary critics in the 1960s saw as a Sjöwall/Wahlöö dystopia (Wendelius 1999). Recent decades have seen cuts in social insurance systems, and there is an increase in the number of poor sick people, poor retired people, poor immigrants and poor children. Economic gaps expand faster in Sweden than in the rest of Europe (Therborn 2018). The critique of institutions not doing what they are supposed to-be it the police, social services, health care, immigration, schools-pours out of the documentaries on murder read as a whole, and does so mainly through interviews with officials from different institutions and authorities. It addresses an awareness of vulnerability-not only to the potential exposure of crime-of large groups, a sense of insecurity, where the welfare state is no longer to be trusted. In this context, one of the manifold appeals of the P3 documentaries could be the built-in Nordic noir dystopia-which many fear is now being realized. The spectacular murder finally solved then becomes reassuring proof of the continued existence of the welfare state.

\section{CONCLUSION}

With their large audiences, one can assume that crime documentaries play an important part in the representation of crime and the justice system, and that they contribute to conceptions that influence public discourse. As Jamie Bennett (2017) puts it, 'Within the criminal justice system', documentaries are important 'not only because of the public fascination with crime and punishment, but also because the everyday workings of the criminal justice system often remain outside of the direct experience or sight of most people'. Even though it is difficult to measure the impact 
in a reliable way, it is safe to say that crime documentaries raise 'significant issues about the representation of the law in the digital era, perceptions of justice, narrative and evidence, the increased "jurification" of audiences and the instability of truth' (Bruzzi 2016, p. 280). However, from the perspective of the implied listener and vulnerability, there is more than the audience being educated about crime and the legal system at work.

P3 Documentary's programmes about murder cases arguably contribute to the circulation, invoking and assembling of emotions in and between listeners in particular ways. They perform both cultural and political work by pushing some of their listeners - vulnerable to emotions linked to victims, perpetrators and family-away from each other while pulling others together (Ahmed 2004, p. 2).

The format of the murder documentaries in P3 Documentary share traits with melodrama and therefore, in controversial cases, moves the listener in certain political directions. The example of honour killings, and the difference between the early (2005) and recent (2016) programmes on the subject, show that while the former was more thoroughly contextualized, the latter was focused on the heightening of emotion and suspense, the juxataposition of good and evil through the repetition of sticky words, the details of horrific violence, and a metonymic sliding and moving about of hate. Due to this, listeners were drawn together in defence of the national subject and, ultimately, the nation as a whole. In addition, P3 Documentary on murder distributes a politics of mobility aimed at women and children by drawing on horror conventions. These aspects are all amplified by the intimacy created by the interviews with the victims' family and friends. They align the listeners through the love of likeness, as well as by the impact of the use of technical devices in the programmes that corresponds to the listeners' own use of it.

Finally, even though one could link the use of experts to the intent to represent reality and truth, to a high degree such experts are used to create suspense, as well as to point to vulnerabilities in the welfare society. The analysis shows that the focus on the listeners' emotional vulnerability through the suspense-driven format complicates P3 Documentary's aim to be impartial. 


\section{Notes}

1. By 'listener' we do not, of course, refer to the empirical listener, but to an 'implied listener' (derived from Iser's [1978] concept of the 'implied reader'), and its responsiveness to the aesthetic traits of the programme.

2. All translations of Swedish texts concerning P3 Documentary (i.e. titles and descriptions from Swedish Radio) are ours.

3 . The running time for each category of voices and their share of the total running time of the 19 documentaries is distributed as follows: Interviewees take up $49.9 \%$. Within this category, family, relatives and acquaintances dominate with $19.5 \%$ of the running time, followed by police and prosecutors (13.8\%) and journalists (3.5\%). External recordings and other sounds make up $15.6 \%$ and $6.8 \%$, respectively, of the total running time.

4. Not only did the number of documentaries on murder increase in the period 2016-2017, so did the average time occupied by the narrator. Between 2005-2015, 11 documentaries on murder were broadcast, with the narrator occupying, on average, $25 \%$ of the running time. In 2016 and 2017, no less than eight P3 documentaries dealt with murder cases and the narrator's share of the running time increased to an average of $32 \%$.

5. All Swedish parties underline the importance of learning Swedish. Some want to make it into a condition for citizenship.

6. Of the 19 documentaries, 12 include the name of the victim in the title. Nine of these documentaries deal with cases where the victims were women.

\section{REFERENCES}

Åberg, C. (2012). Radioanalys: Att undersöka radions lyssnare och program. Lund: Studentlitteratur.

Ahmed, S. (2004). The Cultural Politics of Emotion. Edinburgh: Edinburgh University Press.

Arthur, P. (2005). Extreme makeover: The changing face of documentary. Cineaste, 30(3), 18-23.

Austin, T. (2007). Continuity and Change: The Documentary 'Boom'. Manchester: Manchester University Press.

Bennett, J. (2017). Documentaries about crime and criminal justice. In H. N. Pontell (Ed.), Oxford Research Encyclopedia on Criminology and Criminal Justice. Oxford: Oxford University Press.

Berglund, K. (2017). Död och dagishämtningar: En kvantitativ analys av det tidiga 2000-talets svenska kriminallitteratur (Doctoral dissertation). Uppsala Universitet, Uppsala.

Berlant, L. (2008). The Female Complaint: The Unfinished Business of Sentimentality in American Culture. Durham: Duke University Press. 
Biressi, A. (2004). Inside/out: Private trauma and public knowledge in true crime documentary. Screen, 45(4), 401-412.

Björkman, S. (2009). En lyssnares röst. Stockholm: Carlsson Bokförlag.

BRÅ (The Swedish National Council for Crime Prevention). (2014). Lethal Violence in Sweden 1990-2014: A Description of Trends with a Specific Focus on Firearm Violence. Stockholm: Brottsförebyggande rådet.

BRÅ (The Swedish National Council for Crime Prevention). (2018). Konstaterade fall av dödligt våld: En granskning av anmält dödligt våld 2017. Stockholm: Brottsförebyggande rådet.

Brooks, P. (1995[1976]). The Melodramatic Imagination: Balzac, Henry James, and the Mode of Excess. New Haven: Yale University Press.

Bruzzi, S. (2006). New Documentary. London: Routledge.

Bruzzi, S. (2016). Making a genre: The case of the contemporary true crime documentary. Law and Humanities, 10(2), 249-280.

Butler, J. (1997). The Psychic Life of Power: Theories in Subjection. Stanford: Stanford University Press.

Butler, J. (2004). Precarious Lives: The Powers of Mourning and Violence. New York: Verso.

Cole, A. (2016). All of us are vulnerable, but some are more vulnerable than others: The political ambiguity of vulnerability studies, an ambivalent critique. Critical Horizons, 17(2), 260-277.

Crook, T. (1999). Radio Drama: Theory and Practice. London: Routledge.

Davidsson, P., \& Melin Mandre, Å. (2018). Svenskarna och internet 2018. Stockholm: Internetstiftelsen i Sverige.

Forselius, N., \& Granath, S. (2017). Dödligt våld. In L. Wallin (Ed.), Brottsutvecklingen i Sverige fram till àr 2015. Stockholm: Brottsförebyggande rådet, BRÅ.

Grusin, R. A. (2010). Premediation: Affect and Mediality After 9/11. Basingstoke: Palgrave Macmillan.

Hedemann, B. (2006). Hør og Se. Kristiansand: IJ-forlaget.

Horeck, T. (2014). 'A film that will rock you to your core': Emotion and affect in Dear Zachary and the real crime documentary. Crime Media Culture, 10(2), 151-167.

Jermyn, D. (2007). Crime Watching: Investigating Real Crime TV. London: I. B. Tauris.

Kantar Sifo. (2019). Poddtoppen 2018:2. https://www.kantarsifo.se/nyheter-ochpress/poddtoppen-20182. Accessed January 25, 2019.

Lindgren, M. (2011). Journalism as Research: Developing Radio Documentary Theory from Practice. Perth: Murdoch University.

MacMillan, K. (2016). True crime reporting in early modern England. In H. N. Pontell (Ed.), Oxford Research Encyclopedia on Criminology and Criminal Justice. Oxford: Oxford University Press. 
Massumi, B. (2002). Parables for the Virtual. Durham: Duke University Press.

McHugh, S. A. (2012). Oral history and the radio documentary/feature: Introducing the 'COHRD' form. The Radio Journal: International Studies in Broadcast \& Audio Media, 10(1), 35-51.

McHugh, S. A. (2014). RadioDoc review: Developing critical theory of the radio documentary and feature form. Australian Journalism Review, 36(2), 23-35.

Migrationsinfo.se. (2019, June 18). Den tillfälliga lagen. https://www. migrationsinfo.se/flyktingar/den-tillfalliga-lagen/. Accessed June 3, 2019.

Nichols, B. (1991). Representing Reality: Issues and Concepts in Documentary. Bloomington, IN: Indiana University Press.

Nichols, B. (2001). Introduction to Documentary. Bloomington, IN: Indiana University Press.

Radio, Sveriges. (2014). Public Service-Handbok. Stockholm: Sveriges Radio.

Radio, Sveriges. (2015). Public Service-Redovisning 2014. Stockholm: Sveriges Radio.

Radio, Sveriges. (2016). Public Service-Redovisning. Stockholm: Sveriges Radio.

Radio, Sveriges. (2017). Public Service-Redovisning 2016. Stockholm: Sveriges Radio.

Radio, Sveriges. (2018). Public Service-Redovisning 2017. Stockholm: Sveriges Radio.

Skeggs, B., \& Wood, H. (2012). Reacting to Reality Television: Performance, Audience and Value. London and New York: Routledge.

Stanko, E. (1990). Everyday Violence: How Women and Men Experience Sexual and Physical Danger. London: Pandora.

Therborn, G. (2018). Kapitalet, överbeten och alla vi andra: Klassambället $i$ Sverige - det raidande och det kommande. Lund: Arkiv.

Wendelius, L. (1999). Rationalitet och kaos: Nedslag $i$ svensk kriminalfiktion efter 1965. Hedemora: Gidlund.

Werner, W. G. (2016). Justice on screen-A study of four documentary films on the International Criminal Court. Leiden Journal of International Law, 29(4), 1043-1060. 
Open Access This chapter is licensed under the terms of the Creative Commons Attribution 4.0 International License (http://creativecommons.org/licenses/ by $/ 4.0 /$ ), which permits use, sharing, adaptation, distribution and reproduction in any medium or format, as long as you give appropriate credit to the original author(s) and the source, provide a link to the Creative Commons license and indicate if changes were made.

The images or other third party material in this chapter are included in the chapter's Creative Commons license, unless indicated otherwise in a credit line to the material. If material is not included in the chapter's Creative Commons license and your intended use is not permitted by statutory regulation or exceeds the permitted use, you will need to obtain permission directly from the copyright holder.

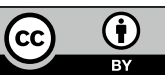

